a mile upstream. On account of these works, a section of the Canadian Railway, two miles in length, had to be re-laid farther inshore. On the Quebec, or western side, immediately adjacent to the power house are 4 sluices, each $40 \mathrm{ft}$. in width, and a log slide ; then a gravity dam, 2,000 ft. long; the 10 Wolverine sluices; another dam, $650 \mathrm{ft}$. long; 22 Merrill Island sluices and, finally, a dam, $2,600 \mathrm{ft}$. long, terminating in a number of short disconnected lengths closing low-lying areas. Alongside the power house, in the foreground of Fig. 3, can be seen the transformer station, consisting of 13 single phase transformèrs, $13 \cdot 2 \mathrm{kv}$. to $220 \mathrm{kv}$., while $800 \mathrm{ft}$. farther along is the $220 \mathrm{kv}$. switching station occupying an area of about $300 \mathrm{ft}$. by $360 \mathrm{ft}$.

Not the least important feature of hydroelectrical exploitation on a national or provincial scale is the regulation of water supplies, and in this connexion the work of the Quebec Streams Commission is worthy of notice. The Commission continues to maintain with every success the desired regulation of flow on all the controlled rivers through its extensive system of storage reservoirs in various parts of the province. It controls seventeen reservoirs, five of which are on the St. Maurice River, two on the St. Francois River, two on the Gatineau River, one at Lake Kenogami for the Sable and Chicoutimi Rivers; three on the North River (Lakes Masson, Long and Bedini) ; two on the St. Anne de Beaupré River (Lakes Brulé and Savane); one on Mitis River and one on Rivière du Lievre. The Commission has also proceeded with the further investigation of storage problems on the Upper Ottawa River, including Jourdan Lake. Numerous lakes have been examined to determine whether they are to be considered as navigable waters, and river profiles have been taken. Studies of ice formation have been made and also sundry investigations of back water and drainage, besides the execution of bank protection work.

1 "Hydro-electric Progress in 1933". By the Hon. Thos. G. Murphy, Minister of the Interior, Ottawa. "Water Power Resources of Canada" Paper No. 1733. Dominion Water Power and Hydrometric Bureau, Ottawa.

2 The Chats Falls Development. Papers by various writers, reprinted from the Engineering Journal, Canada, February and March, 1933.

\title{
World Climate during the Quaternary Period
}

$\mathrm{A}^{\mathrm{T}}$ T the Royal Meteorological Society on May 16, Dr. G. C. Simpson read an important paper on his theory of the climatic variations during the Quaternary Ice Age, with especial reference to its geological implications. Briefly, the theory states that the effect of an increase in the solar radiation intercepted by the earth is a relatively small increase in the earth's temperature, but a large increase in the evaporation, cloudiness and precipitation. In high latitudes or on high mountains, where the precipitation is mainly in the form of snow, the first result is an extension of the icesheets and glaciers, but as the radiation increases still further, the rise of temperature becomes great enough to melt away the ice. If the solar radiation, starting from a minimum, goes through two complete cycles, the climatic succession would be : cold dry climate; glacial ; warm wet interglacial ; glacial ; cold dry interglacial ; glacial ; warm wet interglacial ; glacial ; cold dry climate. Hence there would be four glacial periods separated by three interglacials, of which only the first and third would actually be warm. In low latitudes, on the other hand, the two cycles of radiation would be represented only by two pluvial periods separated by an interpluvial, the maximum of each pluvial coinciding with a warm wet interglacial.

The physical basis of the theory offers no difficulty, requiring only that the earth shall fluctuate in the unstable zone between insufficient snowfall and too great heat. The real test is whether the theory fits the geological facts, and in his latest paper Dr. Simpson arrays an impressive mass of evidence that the fit is very good indeed. Two primary difficulties are first attacked; the centre of glaciation in the northern hemisphere was not the north pole, but lay somewhere in Greenland, while careful analysis by Penck and Brückner has shown that, in the Alps, glaciation was not due to increased snowfall but to decreased temperature. Both these difficulties are explained by the geographical fact that the North Atlantic is open to the Arctic, while the North Pacific is not. During the oncoming of a glacial period there was a great accumulation of floating ice in the Arctic Ocean, and the only outlet through which this could escape led into the Atlantic, which was covered by ice floes down to comparatively low latitudes, while the Pacific was ice-free. This floating ice greatly lowered the temperature of eastern North America and still more of western Europe, and led to the great extension of glaciation in countries bordering on the Atlantic. In the early stages of the Quaternary, however, communication between the Arctic and Atlantic was more or less interrupted by a bar between Greenland and Norway or Scotland; until this bar was submerged, glaciation was unable to develop over the British Isles.

In another respect the classical work of Penck and Brückner in the Alps fits the theory very closely, giving exactly the required sequence of four glacial periods and three interglacials, of which the second was known to be very long compared with the third, while the latter was exceedingly wet and warm. The theory is supported also by recent discoveries in tropical Africa of two great pluvial periods separated by a very dry interpluvial. Archæologically, the third interglacial is dated in Europe by the Acheulean, which is everywhere associated with a warm fauna. From the geological record, Dr. Simpson estimates that at the maximum of the solar radiation the 
temperature was between $5^{\circ} \mathrm{C}$. and $10^{\circ} \mathrm{C}$. higher than at present, and the cloud amount about two tenths greater; from these data he calculated that the sun is a variable star with a range of 40 per cent in the intensity of its radiation.

Since the chief purpose of the paper was the array of geological evidence in support of the theory, the discussion was mainly carried on by the geologists. The present writer gained the impression that the latter accepted the general implications of the theory, but found considerable difficulty in agreeing to the details. On one point, however, there was general agreement: the explanation of the discrepancy between the centre of glaciation and the present north pole by purely geographical reasoning was welcomed as a relief from the difficult assumption of a shift of the poles.

The difficulties of detail are threefold. In the first place, Penck and Brückner's simple scheme of four major glaciations cannot be applied directly to countries outside the Alps. In the British Isles, for example, the succession was much more complicated than that suggested in Dr. Simpson's scheme, and even the number of major glaciations has not yet been determined. The second difficulty concerns the place in the scheme of the archæo- logical stages. Some competent authorities place the Acheulean not in the Riss-Würm interglacial but in the Mindel-Riss, which according to the theory was cold and dry. Even the climate in which Acheulean man lived has not been surely determined, for the interglacial which contains Acheulean implements also includes a loess. Allied to this is the difficulty that the Great Chalky Boulder Clay has features which show that the end of that particular glaciation was dry, though by Dr. Simpson's scheme it leads up to a wet warm interglacial. Finally, one of the fossils used most definitely as an index of a warm climate-Corbicula fluminalis - has recently been found associated with a marine cold fauna, and its climatic value is open to doubt. Dr. Simpson was not worried by these objections, maintaining that if his theory is correct, he had given geologists a useful means of aligning new discoveries, while existing discrepancies would gradually be cleared up.

One interesting point brought out in the discussion was that no difficulty exists from the astronomical point of view in the sun being a variable star. A range of 40 per cent means very little in terms of stellar magnitude, and is unimportant compared with some known variations.

\section{Obituary}

\section{Prof. W. H. Welch}

Tr HE death of Prof. William Henry Welch, of Baltimore, on April 30 at the age of eightyfour years, removes from the scientific world a man who enjoyed an international reputation as a reformer of medical education, sanitarian, pathologist and bacteriologist.

Shortly after obtaining his medical degree at Yale, Welch spent two years in Europe, where he studied normal histology, pathology, physiological chemistry and practical medicine at Strasbourg, Leipzig, Breslau and Vienna under the leading teachers of that day, visited various Paris hospitals and attended Lister's lectures at King's College Hospital, London. He was thus fully equipped with the latest and best medical teaching on his return to New York in the spring of 1878 , where he was soon appointed lecturer on pathology at Bellevue Hospital Medical College.

In 1884 Welch was made professor of pathology at Johns Hopkins University and pathologist to the Johns Hopkins Hospital. Before entering on his new office, he made another journey to Europe, where he studied bacteriology and hygiene under von Pettenkofer, von Flügge and Koch. On his return he played an important part in the development of the Johns Hopkins Hospital, and was largely responsible for the election of the other three original members of the staff, namely, Osler, the physician, Halsted, the surgeon, and Kelly, the gynæcologist, who figure with him in Sargent's well-known picture. From 1893 until 1898 he was dean of the Johns Hopkins Medical
School, being succeeded by Osler. In 1916 he was appointed the first director of the new School of Hygiene and Public Health at Baltimore and held this post until 1926, when he became professor of the history of medicine in the Johns Hopkins University.

Welch's work may be summed up under the headings of sanitation, pathology, bacteriology and medical education. As president of the Maryland State Board of Health - an office which he held for twenty-four years-he played an important part in converting Baltimore, which had hitherto been a focus of typhoid fever, into a healthy city. His advice on sanitary matters was often sought by presidents of the United States and other public authorities, and it was due to him that a Yellow Fever Commission was created, which led to the discovery of the rôle of the mosquito in the spread of the disease. He was the author of numerous important articles on pathology, the best known being those on thrombosis and embolism, which were published in 1899 in Allbutt's "System of Medicine". In 1892 he described the Staphylococcus epidermidis albus and the Bacillus aerogenes capsulatus, the cause of gas gangrene, commonly known as the Welch bacillus.

As medical educationist, Welch is to be credited with having introduced modern methods into the medical schools of the United States and to have trained a large number of pupils, jocularly described as 'Welch rabbits', who afterwards attained a high distinction in the world of medical science. 